\title{
Two new species of Lipurometriocnemus Sæther from Brazil (Diptera: Chironomidae, Orthocladiinae)
}

\author{
Trond Andersen ${ }^{1}$ \\ Luiz C. Pinho ${ }^{2 *}$ \\ Humberto F. Mendes ${ }^{3}$ \\ ${ }^{1}$ University Museum of Bergen, University of Bergen, Department of Natural History \\ P.O. Box 7800, NO-5020 Bergen, Norway \\ ${ }^{2}$ Universidade Federal de Santa Catarina, Centro de Ciências Biológicas \\ Departamento de Ecologia e Zoologia, CEP 88040-901, Florianópolis - SC, Brazil \\ ${ }^{3}$ Universidade Federal de Alfenas, Instituto de Ciências da Natureza \\ Rua Gabriel Monteiro da Silva, 700, CEP 37130-000 Alfenas - MG, Brazil \\ * Corresponding author \\ luiz.pinho@ufsc.br
}

Submetido em 03/06/2015

Aceito para publicação em 07/10/2015

\section{Resumo}

Duas novas espécies de Lipurometriocnemus Sæther do Brasil (Diptera: Chironomidae, Orthocladiinae). Lipurometriocnemus amazonicus $\mathrm{n}$. sp. de Manaus (Amazonas) e L. biancae $\mathrm{n}$. sp. de Urubici (Santa Catarina) são descritos e ilustrados com base nos machos. Lipurometriocnemus amazonicus n. sp. pode ser separado das demais espécies de Lipurometriocnemus pela ausência de cerdas em $\mathrm{R}_{1}$ e $\mathrm{R}_{4+5}$; volsela inferior comparativamente longa e não pronunciada; dorsocentrais em número comparativamente reduzido, em sua maioria unisseriais; e baixa razão antenal. Lipurometriocnemus biancae $\mathrm{n}$. $\mathrm{sp}$. pode ser separado por apresentar cerdas em $\mathrm{R}_{1}$ e $\mathrm{R}_{4+5}$; uma volsela inferior distinta e arredondada; e dorsocentrais de bi- a trisseriais. Emendas à descrição do gênero e chave para machos de todas as espécies conhecidas são fornecidas.

Palavras-chave: Amazônia; Descrições; Mata Atlântica; Região Neotropical; Taxonomia

\section{Abstract}

Lipurometriocnemus amazonicus n. sp. from Manaus in the Amazon and L. biancae n. sp. from Urubici in Santa Catarina State are described and illustrated as males. Lipurometriocnemus amazonicus n. sp. can be separated from other described Lipurometriocnemus species because it lacks setae on the $\mathrm{R}_{1}$ and $\mathrm{R}_{4+5}$; has a comparatively long, low inferior volsella; comparatively few, mostly uniserial dorsocentrals; and a low AR. Lipurometriocnemus biancae $\mathrm{n}$. sp. differs because it has setae on both $\mathrm{R}_{1}$ and $\mathrm{R}_{4+5}$; ; distinct, rounded inferior volsella; and bi- to triserial dorsocentrals. The generic description is emended and a key to the males of all known species is provided.

Key words: Amazon; Atlantic Forest; Descriptions; Neotropical region; Taxonomy 


\section{Introduction}

The genus Lipurometriocnemus Sæther was erected by Sæther (1981) based on L. glabalus Sæther from St. Vincent and St. Lucia in the British West Indies. Later, Sæther (1982) described L. vixlobatus Sæther from North Carolina and Georgia, U.S.A.; this species has also been recorded from the Yukon Territory, Canada (CRANSTON; OLIVER, 1988). The genus is similar to Bryophaenocladius Thienemann and Metriocnemus van der Wulp, but differs from both by the absence of an anal point and from the latter by the absence of setae on the wing membrane.

During fieldwork in Brazil, two new species of Lipurometriocnemus were collected, L. amazonicus $\mathrm{n}$. sp. from the Amazon rain forest and L. biancae n. sp. from the Atlantic Forest in southern Brazil. Both species are described and illustrated below based on male adults.

\section{Material and Methods}

The specimens examined were collected in light traps or Malaise traps and preserved in alcohol. They were later mounted in Canada Balsam following the procedure outlined by Sæther (1969). The general morphology follows Sæther (1980).

The holotypes will be deposited in the Museu de Zoologia da Universidade de São Paulo (MZUSP), São Paulo, Brazil. Paratypes will be kept in the Department of Natural History (ZMBN), Bergen University Museum, University of Bergen, Norway, and at MZUSP.

\section{Results}

\section{Lipurometriocnemus Sæther}

Lipurometriocnemus Sæther, 1981: 13.

Lipurometriocnemus Sæther (1982); Cranston et al. (1989); Mendes and Pinho (2011).

Type species: Lipurometriocnemus glabalus Sæther, 1981.

Additional species: L. amazonicus n. sp., L. biancae n. sp. and L. vixlobatus Sæther, 1982.
The genus was described by Sæther (1981). A few emendations were given in Sæther (1982), and Ferrington Jr and Sæther (1995) added that L. vixlobatus has a palpal projection. With the inclusion of the two new species from Brazil, the description has to be further emended.

\section{Emended description}

Small to medium-sized species, with wing length 1.0-2.1 $\mathrm{mm}$.

Antenna. Male antenna with 13 flagellomeres, plumose, groove beginning at flagellomere 3 or 4; sensilla chaetica on flagellomeres 2, 3 and 13; without strong apical seta. Antennal ratio $1.2-1.8$.

Head. Eye bare, without or with short wedge-shaped dorsomedial extension. Temporal setae in single row, consisting of inner and outer verticals, postorbitals generally few or absent. Palp with 5 segments, normal. Apex of palpomere 3 with 2-8 sensilla clavata, sometimes with finger-like extension.

Thorax. Antepronotum well developed, median lobes not narrowed and joined anteriorly at suture, with several lateral antepronotals. Acrostichals strong to weak, beginning near antepronotum; dorsocentrals generally numerous, uni- to multiserial at least anteriorly; several prealars present, supraalar present or absent. Scutellum with single or double row of scutellars, posterior setae strongest.

Wing. Anal lobe well developed. Membrane without setae, with strong microtrichia. Costa slightly to moderately extended; $\mathrm{R}_{2+3}$ running and ending about midway between $\mathrm{R}_{1}$ and $\mathrm{R}_{4+5} ; \mathrm{R}_{4+5}$ ending distal to end of $\mathrm{M}_{3+4}$; $\mathrm{FCu}$ far distal to $\mathrm{RM}$; $\mathrm{Cu}_{1}$ straight; An ending opposite or proximal to $\mathrm{FCu}$. Brachiolum with 1-3 setae, $R$ with setae, $R_{1}$ and $R_{4+5}$ with or without setae. Squama with several setae.

Legs. Tibial spurs and comb normal. Mid and hind legs with pseudospurs on tarsomeres $1-3$. Sensilla chaetica and pulvilli absent.

Abdomen. Tergites with evenly scattered setae in about 4-5 irregular transverse rows.

Hypopygium. Anal point absent or represented by more or less pronounced dorsal hump with several setae. 
Sternapodeme nearly straight to slightly rounded, oral projections vestigial to weak. Virga vestigial or small, nail-shaped. Gonocoxite with vestigial to distinct, rounded inferior volsella. Gonostylus club-shaped, with short crista dorsalis.

\section{Key to the males of Lipurometriocnemus Sæther}

1. $\mathrm{R}_{1}$ and $\mathrm{R}_{4+5}$ without setae 2

$-\mathrm{R}_{1}$ with setae, $\mathrm{R}_{4+5}$ with or without setae. .. 3

2. With 25-31 dorsocentrals, mostly bi - to triserial; $\mathrm{AR}=1.60-1.75$. USA. L. vixlobatus Sæther

- With 9-19 dorsocentrals, mostly uniserial; $\mathrm{AR}=1.23-1.45$. Brazil. L. amazonicus $\mathrm{n}$. $\mathrm{sp}$.

3. Without inferior volsella; $\mathrm{R}_{1}$ with 2 setae, $\mathrm{R}_{4+5}$ without setae. British West Indies. L. glabalus Sæther

- With distinct, rounded inferior volsella; $\mathrm{R}_{1}$ with 11-18 setae, $\mathrm{R}_{4+5}$ with 8-27 setae. Brazil L. biancaen. sp.

\section{Lipurometriocnemus amazonicus n. sp.}

(Figures 1-6)

\section{Type material}

Holotype male: Brazil, Amazonas State, Manaus, Reserva Adolpho Ducke, Igarapé Barro Branco, 02 55'47'S 5958'22”W, 5-8 February 2010, light trap, leg. L.C. Pinho \& H.F. Mendes (MZUSP). Paratypes: 8 males as holotype (MZUSP, ZMBN).

\section{Diagnostic characters}

The species differs from other described Lipurometriocnemus species because it lacks setae on the $\mathrm{R}_{1}$ and $\mathrm{R}_{4+5}$; has a comparatively long, low inferior volsella; comparatively few, mostly uniserial dorsocentrals; and a low AR.

\section{Description}

Male ( $\mathrm{n}=6-9)$. Total length 2.41-2.90, $2.65 \mathrm{~mm}$. Wing length 1.14-1.40, $1.23 \mathrm{~mm}$. Total length / wing length 2.08-2.30, 2.17. Wing length / length of profemur $2.05-2.22,2.11$.

Coloration. Head, thorax and abdomen brown, legs slightly lighter brown.

Antenna. AR 1.23-1.48, 1.33. Ultimate flagellomere 452-564, $496 \mu \mathrm{m}$ long.

Head (Figure 1). Temporal setae 8-10, 9 including $5-7,5$ inner verticals, 2-4, 3 outer verticals and $0-1$, 0 postorbitals. Clypeus with $7-14,9$ setae. Tentorium, stipes, and cibarial pump as in Figure 2. Tentorium 109 125, $114 \mu \mathrm{m}$ long; 21-27, $24 \mu \mathrm{m}$ wide. Stipes 107-127, $114 \mu \mathrm{m}$ long; $33-45,38 \mu \mathrm{m}$ wide. Palp segment lengths (in $\mu \mathrm{m}$ ): $23-29,26$; 37-49, 44; 115-131, 124; 86-117, $106 ; 119-162,142$. Third palpomere with $2-5,4$ sensilla clavata in apical one-half, longest 15-18, $17 \mu \mathrm{m}$ long.

Thorax (Figure 3). Antepronotum with 2-6, 4 lateral setae. Acrostichals 12-16, 14; dorsocentrals 9-19, 14, uniserial to partly biserial; prealars $4-8,6$; supraalar absent. Scutellum with 5-8, 7 setae.

Wing (Figure 4). VR 1.31-1.41, 1.36. Costal extension 55-94, $72 \mu \mathrm{m}$ long. Brachiolum with 1-3, 2 setae, $\mathrm{R}$ with $3-8$, 5 setae, remaining veins and cells bare. Squama with $8-12,10$ seta, partly biserial.

Legs. Spur of fore tibia 45-54, $49 \mu \mathrm{m}$ long, spurs of mid tibia $30-36,32 \mu \mathrm{m}$ and $28-33,30 \mu \mathrm{m}$ long, spurs of hind tibia 47-55, $52 \mu \mathrm{m}$ and 27-29, $28 \mu \mathrm{m}$ long. Width at apex of fore tibia $32-36,34 \mu \mathrm{m}$, of mid tibia $32-36$, $34 \mu \mathrm{m}$, of hind tibia $36-41,39 \mu \mathrm{m}$. Comb with $8-9,8$ setae, longest 37-41, $39 \mu \mathrm{m}$ long, shortest $22-28,25 \mu \mathrm{m}$ long. Length (in $\mu \mathrm{m}$ ) of pseudospurs of $\mathrm{ta}_{1}-\mathrm{ta}_{3}$ on mid leg as: $33-39,36$ and $29-32,28 ; 30-36,33$ and $28-32,29$; $26-35,30$ and $25-30,28$. Length (in $\mu \mathrm{m}$ ) of pseudospurs of $\mathrm{ta}_{1}-\mathrm{ta}_{3}$ on hind leg as: $33-36,35$ and $30-33,31 ; 33-37$, 35 and $29-33,32 ; 29-35,33$ and $28-32,30$. Lengths and proportions of legs as in Table 1. 
FIGURES 1-4: Lipurometriocnemus amazonicus n. sp., male: 1, head; 2, tentorium, stipes and cibarial pump; 3, thorax; 4, wing.

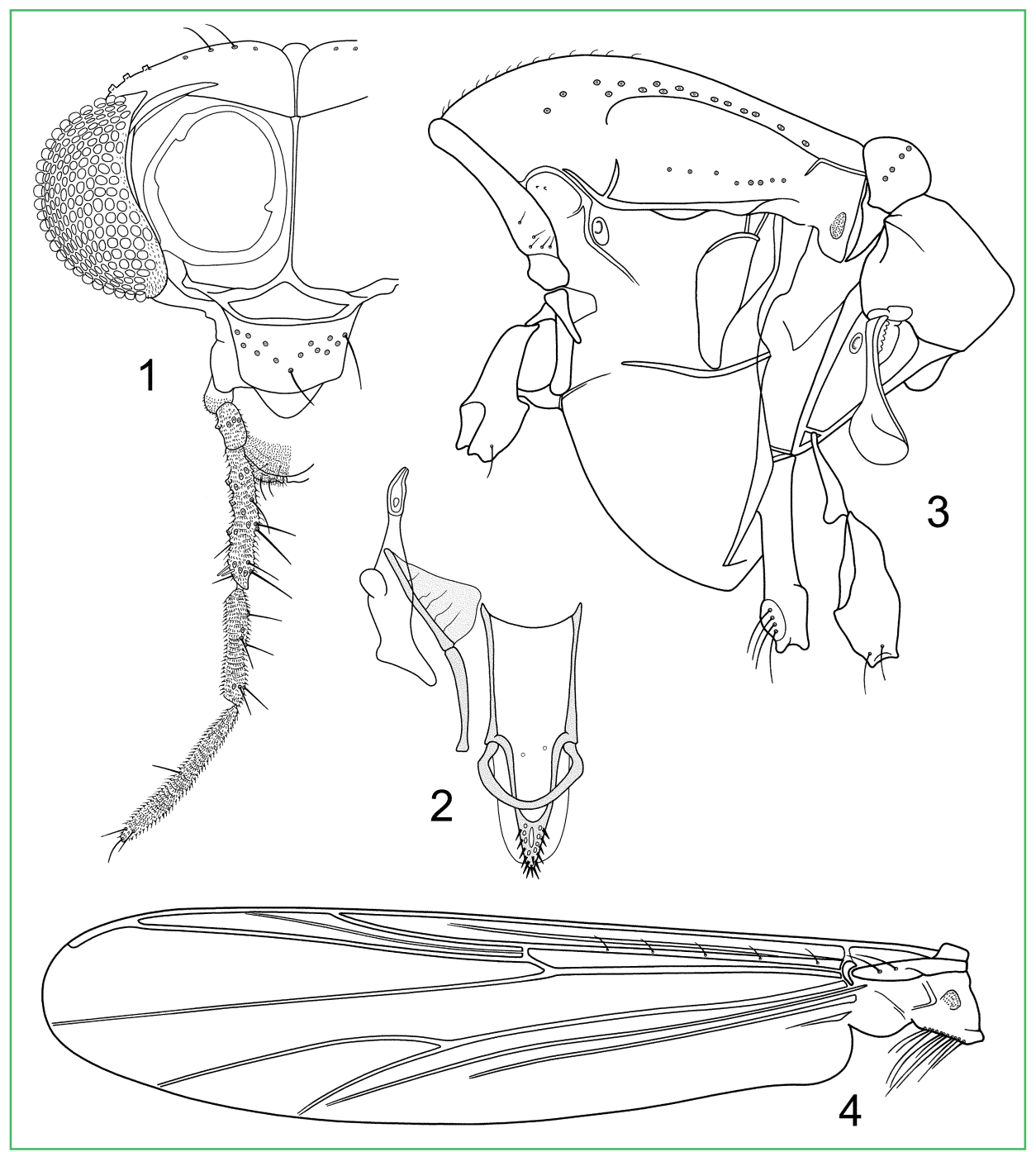

TABLE 1: Lengths (in $\mu \mathrm{m}$ ) and proportions of legs of Lipurometriocnemus amazonicus $\mathrm{n}$. $\mathrm{sp}$., male ( $\mathrm{n}=5-6$, if not otherwise stated).

\begin{tabular}{lllll}
\hline & \multicolumn{1}{c}{$\mathbf{f e}$} & \multicolumn{1}{c}{$\mathbf{t i}$} & \multicolumn{1}{c}{$\mathbf{t a}_{\mathbf{1}}$} & \multicolumn{1}{c}{$\mathbf{t a}_{\mathbf{2}}$} \\
\hline $\mathrm{p}_{1}$ & $523-629,585$ & $588-727,660$ & $400-531,487$ & $245-335,302$ \\
$\mathrm{p}_{2}$ & $507-605,559$ & $498-662,585$ & $253-343,317$ & $139-188,172$ \\
$\mathrm{p}_{3}$ & $523-645,575$ & $605-792,712$ & $351-458,417$ & $188-245,224$ \\
\hline & $\mathbf{t a}_{3}$ & $\mathbf{t a}_{4}$ & $\mathbf{t a}_{5}$ & $\mathbf{L R}$ \\
\hline $\mathrm{p}_{1}$ & $155-221,194$ & $98-123,114$ & $49-57,54$ & $0.68-0.76,0.74$ \\
$\mathrm{p}_{2}$ & $98-139,129$ & $65-82,77$ & $33-41,39$ & $0.51-0.58,0.54$ \\
$\mathrm{p}_{3}$ & $147-196,173$ & $74-106,87$ & $33-49,46$ & $0.58-0.60,0.59$ \\
\hline & $\mathbf{B V}$ & \multicolumn{2}{c}{$\mathbf{S V}$} & $\mathbf{B R}$ \\
\hline $\mathrm{p}_{1}$ & $2.49-2.73,2.61$ & $2.48-2.78,2.57$ & $3.5-3.7(3)$ \\
$\mathrm{p}_{2}$ & $3.37-3.76,3.50$ & $3.41-3.97,3.62$ & $3.0-3.6,3.5$ \\
$\mathrm{p}_{3}$ & $3.16-3.35,3.23$ & $3.02-3.21,3.09$ & $4.8-6.0,5.3$ \\
\hline
\end{tabular}


Hypopygium (Figures 5-6). Tergite IX with 14-27, 18 setae. Laterosternite IX with 3-6, 4 setae. Transverse sternapodeme nearly straight with weak oral projections, 63-70, $67 \mu \mathrm{m}$ long. Phallapodeme 75-83, $79 \mu \mathrm{m}$ long. Virga small, nail-shaped, 7-10, $8 \mu \mathrm{m}$ long. Gonocoxite 174-197, $190 \mu \mathrm{m}$ long; with 49-57, $52 \mu \mathrm{m}$ long, 8-13, $10 \mu \mathrm{m}$ wide inferior volsella, ending $55-74,65 \mu \mathrm{m}$ from apex of gonocoxite. Gonostylus 94-111, $105 \mu \mathrm{m}$ long, 23-27, $25 \mu \mathrm{m}$ wide medially; megaseta $14-17,15 \mu \mathrm{m}$ long. HR 1.72-1.90, 1.82. HV 2.21-2.71, 2.52.

Female and immatures. Unknown.

\section{Distribution and ecology}

The species is only known from the type locality, Reserva Adolpho Ducke, a 10,000 ha reserve on the outskirts of Manaus, Amazonas State, Brazil. The specimens were collected in a light trap situated close to a stream and several temporary pools. The area is covered with primary forest and is relatively flat. During the rainy season numerous small pools form, which are scattered on the forest floor.

Reserva Adolpho Ducke is also the type locality for Dicrotendipes fittkaui Epler, Litocladius neusae Mendes, Andersen et Hagenlund, Beardius curticaudatus Pinho, Mendes et Andersen, Ablabesmyia communiba Neubern, Ablabesmyia ducke Neubern, Mariambera mariae Andersen, Mendes et Pinho, Saetherocryptus amazonicus Andersen et Pinho, Thalassosmittia amazonica Andersen et Pinho and Titimbera amazonica Andersen, Pinho et Mendes (EPLER, 1988; MENDES et al., 2011; PINHO et al., 2013; OLIVEIRA et al., 2013; ANDERSEN; PINHO, 2014a; 2014b; ANDERSEN et al., 2015a; 2015b).

\section{Etymology}

Named after the Amazon region, where the type specimen was collected.

FIGURES 5-6: Lipurometriocnemus amazonicus n. sp., male: 5, hypopygium, dorsal view; 6, hypopygium with anal point and tergite IX removed, dorsal aspect to the left and ventral aspect to the right.

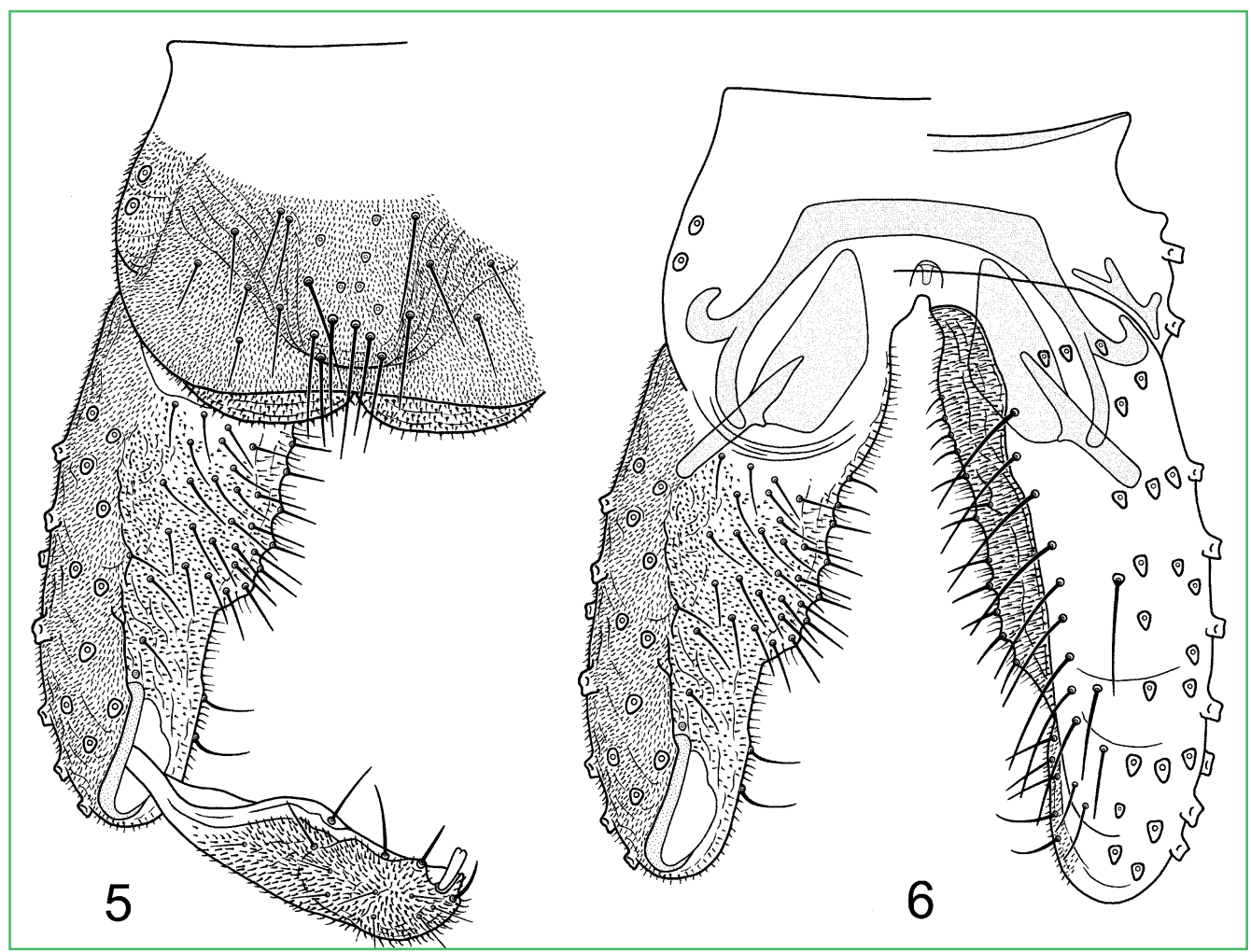




\section{Lipurometriocnemus biancae n. sp.}

(Figures 7-11)

\section{Type material}

Holotype: male: BRAZIL, Santa Catarina State, Urubici, Morro da Igreja, Parque Nacional de São Joaquim, Rio

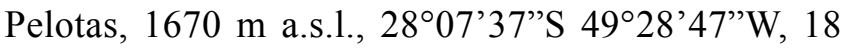
September-5 December 2004, Malaise trap, cloud forest, leg. L.C. Pinho \& L.E.M. Bizzo (MZUSP). Paratypes: 3 males, as holotype (MZUSP, ZMBN).

\section{Diagnostic characters}

The species differs from other described Lipurometriocnemus species because it has setae on both $\mathrm{R}_{1}$ and $\mathrm{R}_{4+5}$; a distinct, rounded inferior volsella; and bi- to triserial dorsocentrals.

\section{Description}

Male ( $\mathrm{n}=4$, if not otherwise stated). Total length $3.17-4.09,3.63 \mathrm{~mm}$. Wing length 1.96-2.19, $2.11 \mathrm{~mm}$. Total length / wing length 1.45-1.67, 1.59. Wing length / length of profemur 2.14-2.29, 2.23.

Coloration. Head and thorax dark brown, abdomen brown, legs slightly lighter brown.

Antenna. AR 1.29-1.45 (3). Ultimate flagellomere 572-613 (3) $\mu \mathrm{m}$ long.

Head. Temporal setae 12-14, 13 including 6-7, 7 inner verticals, 4 outer verticals and 2-3, 2 postorbitals. Clypeus with 10-32, 23 setae. Tentorium, stipes, and cibarial pump as in Figure 7. Tentorium 168-185, 175 $\mu \mathrm{m}$ long; 35-43, $39 \mu \mathrm{m}$ wide. Stipes $170-185,178 \mu \mathrm{m}$ long; 45-62, $55 \mu \mathrm{m}$ wide. Palp segment lengths (in $\mu \mathrm{m}$ ): 29-41, 34; 51-68, 60; 199-269, 224; 152-205, 173; 213-256, 230. Third palpomere with 4-8, 5 sensilla clavata in apical one-half, longest $17-21,19 \mu \mathrm{m}$ long.

FIGURES 7-9: Lipurometriocnemus biancae n. sp., male: 7, tentorium, stipes and cibarial pump; 8, thorax; 9, wing.

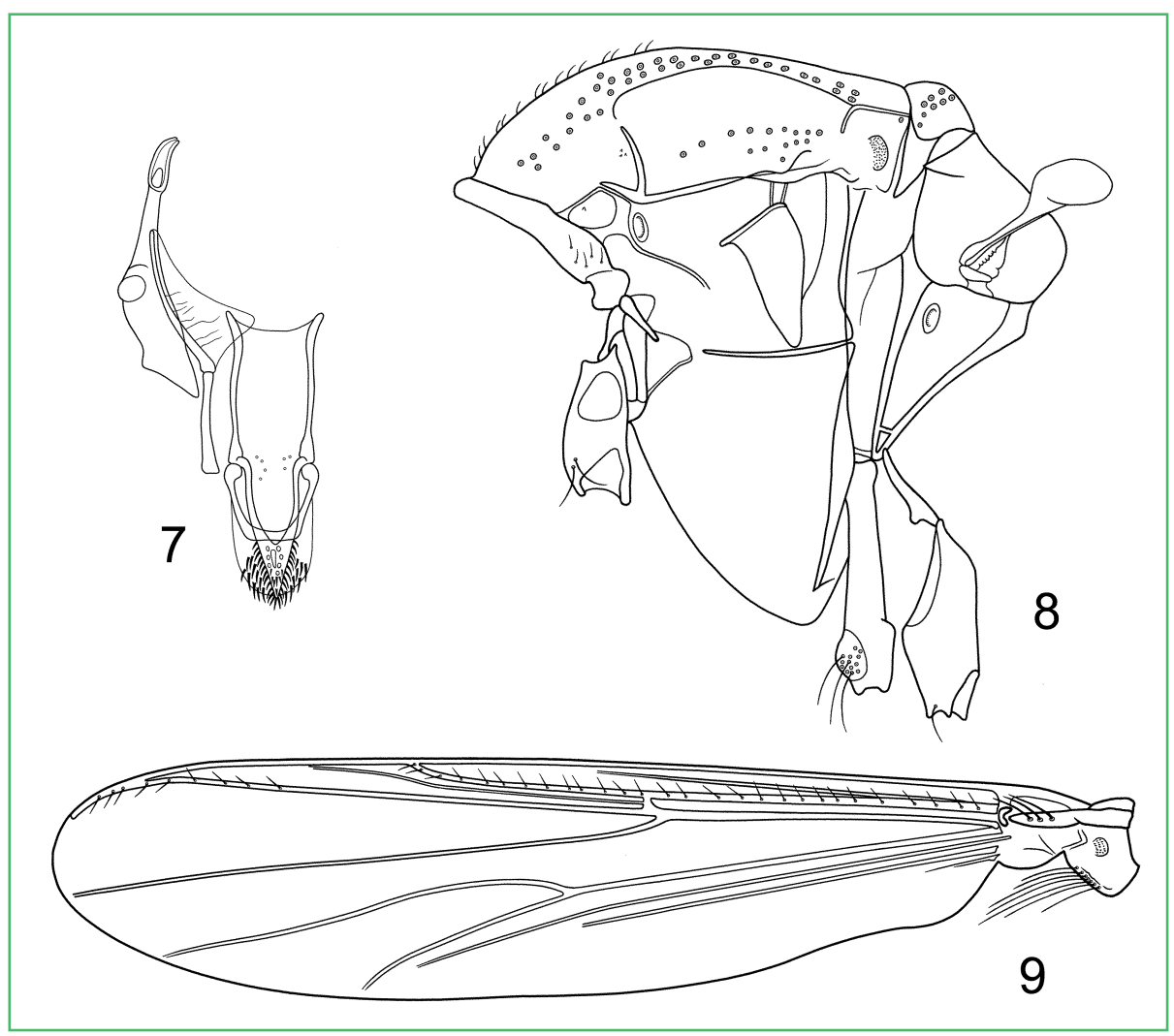


Thorax (Figure 8). Antepronotum with 3-8, 5 lateral setae. Acrostichals weak, apparently about 10; dorsocentrals 24-36, 31, biserial; prealars 12-13, 13, biserial; supraalar 0-1, 1. Scutellum with 14-20, 17 setae, partly biserial.

Wing (Figure 9). VR 1.34-1.36, 1.35. Costal extension 94-117, $104 \mu \mathrm{m}$ long. Brachiolum with 2-3, 3 setae; $\mathrm{R}$ with $15-22,18$ setae; $\mathrm{R}_{1}$ with $11-18,14$ setae; $\mathrm{R}_{4+5}$ with 8-27, 17 setae; costal extension with 1-3, 2 nonmarginal setae. Squama with 10-14, 12 setae, partly biserial.

Legs. Spur of fore tibia 76-92, $82 \mu \mathrm{m}$ long; spurs of mid tibia 55-68, $61 \mu \mathrm{m}$ and 36-49, $43 \mu \mathrm{m}$ long; spurs of hind tibia 88-95, $93 \mu \mathrm{m}$ and $36-44,40 \mu \mathrm{m}$ long. Width at apex of fore tibia 48-58, $52 \mu \mathrm{m}$, of mid tibia 48-61, $54 \mu \mathrm{m}$, of hind tibia $61-68,63 \mu \mathrm{m}$. Comb with 12 setae, longest 62-73, $69 \mu \mathrm{m}$ long, shortest 30-33, $32 \mu \mathrm{m}$ long. Length (in $\mu \mathrm{m}$ ) of pseudospurs of $\mathrm{ta}_{1}-\mathrm{ta}_{3}$ on mid leg as: 46-62, 54 and 43-52, 49; 43-51, 49 and 41-51, 47; 41-49, 47 and 40-44, 43. Length (in $\mu \mathrm{m}$ ) of pseudospurs of $\mathrm{ta}_{1}-\mathrm{ta}_{3}$ on hind leg as: 47-58, 52 and 44-52, 49; 44-57, 50 and 43-51, 47; 44-50, 47 and 40-47, 43. Lengths and proportions of legs as in Table 2.

Hypopygium (Figures 10-11). Tergite IX with 24-38, 31 setae. Laterosternite IX with 4-5, 5 setae. Transverse sternapodeme arched with weak oral projections,
94-117, $102 \mu \mathrm{m}$ long. Phallapodeme 97-109, $103 \mu \mathrm{m}$ long. Virga nail-shaped, 15-21, $18 \mu \mathrm{m}$ long. Gonocoxite 221-255, $234 \mu \mathrm{m}$ long; with 39-44, $42 \mu \mathrm{m}$ long, 14-21, $18 \mu \mathrm{m}$ wide inferior volsella, ending 79-94, $89 \mu \mathrm{m}$ from apex of gonocoxite. Gonostylus 119-126, $123 \mu \mathrm{m}$ long, 32-39, $35 \mu \mathrm{m}$ wide medially; megaseta 17-19, $18 \mu \mathrm{m}$ long. HR 1.80-2.15, 1.91. HV 2.52-2.90, 2.75.

Female and immatures. Unknown.

\section{Distribution and ecology}

The species is known only from the type locality, Morro da Igreja, in Urubici, Santa Catarina State, southern Brazil. It was collected in a Malaise trap in an area with cloud forest above 1,600 m elevation. The area is part of the Brazilian Pine Forest subregion of the Atlantic Forest (SILVA; CASTELETI, 2003).

Morro da Igreja is also the type locality for Pseudosmittia catarinense Andersen, Sæther et Mendes, Pseudosmittia gibbistyla Andersen, Sæther et Mendes, Pseudosmittia pinhoi Andersen, Sæther et Mendes, Saetherocladius urubiciensis Andersen, Mendes et Pinho, Saetherocladius fusus Andersen, Mendes et Pinho, Lopescladius vibrissatus Hagenlund, Andersen et Mendes, Miambera miae Andersen et Mendes, Oukuriella pinhoi Fusari, Roque et Hamada, Xestochironomus virgoferreae Pinho et Souza, Beardius

TABLE 2: Lengths (in $\mu \mathrm{m}$ ) and proportions of legs of Lipurometriocnemus biancae n. sp., male ( $\mathrm{n}=4$, if not otherwise stated).

\begin{tabular}{lllll}
\hline & $\mathbf{f e}$ & $\mathbf{t i}$ & $\mathbf{t a}_{\mathbf{1}}$ & $\mathbf{t a}_{\mathbf{2}}$ \\
\hline $\mathrm{p}_{1}$ & $874-1062,960$ & $956-1201,1066$ & $694-850,784$ & $376-449,425$ \\
$\mathrm{p}_{2}$ & $801-956,893$ & $825-1070,940$ & $417-531,470$ & $245-294,268$ \\
$\mathrm{p}_{3}$ & $874-1005,958$ & $1070-1373,1230$ & $556-694,639$ & $302-368,339$ \\
\hline & $\mathbf{t a}_{\mathbf{3}}$ & $\mathbf{t a}_{4}$ & $\mathbf{t a}_{\mathbf{5}}$ & $\mathbf{L R}$ \\
\hline $\mathrm{p}_{1}$ & $253-319,294$ & $155-201,184$ & $76-98,86$ & $0.71-0.77,0.74$ \\
$\mathrm{p}_{2}$ & $180-229,204$ & $106-147,127$ & $65-82,76$ & $0.47-0.53,0.50$ \\
$\mathrm{p}_{3}$ & $229-278,263$ & $123-163,145$ & $63-82,76$ & $0.51-0.55,0.52$ \\
\hline & $\mathbf{B V}$ & $\mathbf{S V}$ & $\mathbf{B R}$ \\
\hline $\mathrm{p}_{1}$ & $2.77-2.98,2.91$ & $2.44-2.66,2.59$ & $2.9-3.2,3.1$ \\
$\mathrm{p}_{2}$ & $3.38-3.44,3.42$ & $3.77-4.15,3.91$ & $2.9-3.4,3.0$ \\
$\mathrm{p}_{3}$ & $3.38-3.48,3.44$ & $3.28-3.51,3.42$ & $4.2-6.4(3)$ \\
\hline
\end{tabular}


FIGURES 10-11: Lipurometriocnemus biancae n. sp., male: 10, hypopygium, dorsal view; 11, hypopygium with anal point and tergite IX removed, dorsal aspect to the left and ventral aspect to the right.

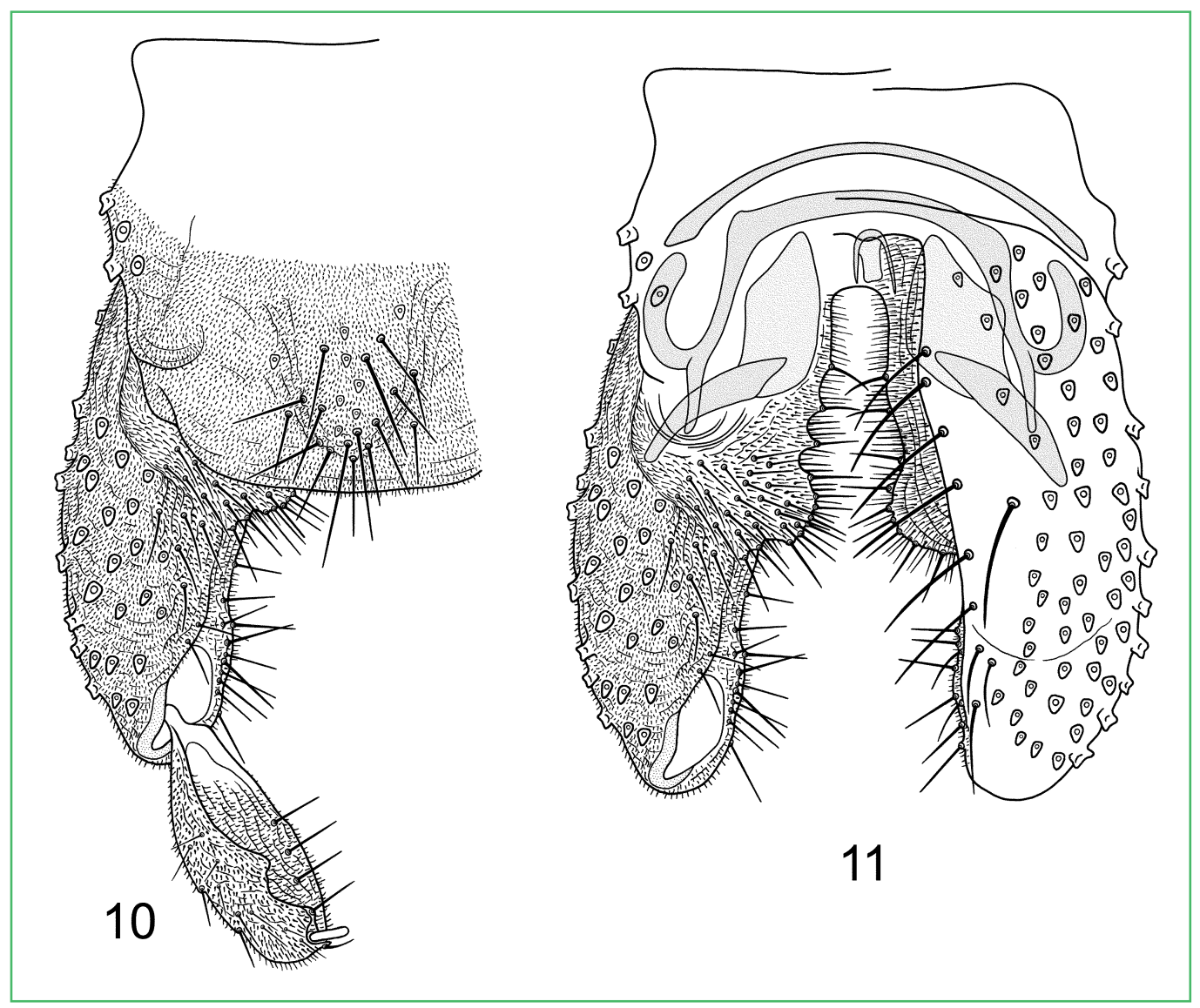

bizzoi Pinho, Mendes et Andersen, Beardius mileneae Pinho, Mendes et Andersen and Beardius nebularius Pinho, Mendes et Andersen (ANDERSEN et al., 2010a; 2010b; HAGENLUND et al., 2010; ANDERSEN; MENDES, 2012; FUSARI et al., 2013; PINHO; SOUZA, 2013; PINHO et al., 2013).

\section{Etymology}

Named after Bianca Cecilie Nygård (University of Bergen) for all support related to fieldtrips to South America.

\section{Acknowledgements}

We are indebted to Dr. Neusa Hamada (Instituto Nacional de Pesquisas da Amazônia, Manaus) for setting up the project to increase the knowledge about aquatic insects in Amazonas State. Gladys Ramirez made the slide preparations. Financial support for fieldwork in Amazonas was provided through a project supported by PRONEX-CNPq (MCT)-FAPEAM (Insetos aquáticos: biodiversidade, ferramentas ambientais e a popularização da ciência para melhoria da qualidade de vida humana no estado do Amazonas) and INPA (MCT).

\section{References}

ANDERSEN, T.; MENDES, H. F. Miambera miae n. gen., n. sp. from southern Brazil (Diptera: Chironomidae, Orthocladiinae). Biota Neotropica, v. 12, p. 105-109, 2012.

ANDERSEN, T.; MENDES, H. F.; PINHO, L. C. Four new species of Saetherocladius Andersen et Mendes from Mata Atlântica, Brazil (Diptera: Chironomidae: Orthocladiinae). Zootaxa, Auckland, v. 2608, p. 45-56, 2010a. 
ANDERSEN, T.; MENDES, H. F.; PINHO, L. C. Mariambera, a new genus of Orthocladiinae from Brazil (Insecta: Diptera, Chironomidae). Studies on Neotropical Fauna and Environment, Tübingen, v. 50, n. 1, p. 24-30, 2015a.

ANDERSEN, T.; MENDES, H. F.; PINHO, L. C. Titimbera, a new genus of Orthocladiinae from South and Central America (Diptera: Chironomidae). Studies on Neotropical Fauna and Environment, Tübingen, v. 50, n. 2, p. 96-106, 2015 b.

ANDERSEN, T.; PINHO, L. C. A new species of Saetherocryptus Andersen et Mendes, 2007 (Diptera: Chironomidae, Orthocladiinae) from the Amazon rainforest, Brazil. Norwegian Journal of Entomology, Oslo, v. 61, p. 160-164, 2014a.

ANDERSEN, T.; PINHO, L. C. A new Thalassosmittia Strenzke \& Remmert, 1957 out of the sea: T. amazonica n. sp. from the Amazon rainforest, Brazil (Diptera: Chironomidae, Orthocladiinae). Chironomus Newsletter on Chironomidae Research, Trondheim, v. 27 , p. $25-30,2014 b$.

ANDERSEN, T.; SÆTHER, O. A.; MENDES, H. F. Neotropical Allocladius Kieffer, 1913 and Pseudosmittia Edwards, 1932 (Diptera: Chironomidae). Zootaxa, Auckland, v. 2472, p. 1-77, 2010b.

CRANSTON, P. S.; OLIVER, D. R. Additions and corrections to the Nearctic Orthocladiinae (Diptera: Chironomidae). The Canadian Entomologist, Ottawa, v. 120, p. 425-462, 1988.

CRANSTON, P. S.; OLIVER, D. R.; SÆTHER, O. A. The adult males of Orthocladiinae (Diptera: Chironomidae) of the Holarctic region - Keys and diagnoses. Entomologica Scandinavica, Supplement, Lund, v. 34, p. 165-352, 1989.

EPLER, J. H. Biosystematics of the genus Dicrotendipes Kieffer, 1913 (Diptera: Chironomidae) of the world. Memoirs of the American Entomological Society, Philadelphia, v. 36, p. 1-214, 1988.

FERRINGTON JR, L. C.; SÆTHER, O. A. Afrotropical species of Parakiefferiella Thienemann, with a review of species with palpal projections (Diptera: Chironomidae). In: CRANSTON, P. S. (Ed.). Chironomids: from genes to ecosystems. East Melbourne: CSIRO Australia, 1995. p. 369-377.

FUSARI, L. M.; ROQUE, F. O.; HAMADA, N. Systematics of Oukuriella Epler, 1986, including a revision of the species associated with freshwater sponges. Insect Systematics and Evolution, Stuttgart, v. 44, p. 1-41, 2013.
HAGENLUND, L. K.; ANDERSEN, T.; MENDES, H. F. New species of Lopescladius (Cordiella) Coffman et Roback (Chironomidae: Orthocladiinae) from Brazil. Zootaxa, Auckland, v. 2728 , p. $39-49,2010$.

MENDES, H. F.; ANDERSEN, T.; HAGENLUND, L. K. New species and records of Antillocladius Sæther and Litocladius Mendes, Andersen et Sæther from Brazil and Costa Rica (Chironomidae: Orthocladiinae). Zootaxa, Auckland, v. 2915, p. 39-51, 2011.

MENDES, H. F.; PINHO, L. C. Checklist of the Brazilian Chironomidae species. 2011. Available at: $<$ https://sites.google. com/site/brazilianchironomids/list>. Accessed: 20 may 2015.

OLIVEIRA, C. S.; SILVA, M. A. N.; FONSECA-GESSNER, A. A. Neotropical Ablabesmyia Johannsen (Diptera: Chironomidae, Tanypodinae). Part I. Zootaxa, Auckland, v. 3733, p. 1-123, 2013.

PINHO, L. C.; MENDES, H. F.; ANDERSEN, T. Revision of Beardius Reiss et Sublette, 1985 (Diptera: Chironomidae), with the description of twenty new species. Zootaxa, Auckland, v. 3742, p. 1-78, 2013.

PINHO, L. C.; SOUZA, J. F. New species of Xestochironomus Sublette et Wirth, 1972 (Diptera: Chironomidae) from Atlantic Forest, Brazil. Zootaxa, Auckland, v. 3652, p. 595-600, 2013.

SILVA, J. M. C.; CASTELETI, C. H. M. Status of the biodiversity of the Atlantic Forest of Brazil. In: GALINDO-LEAL, C.; CÂMARA, I. G. (Ed.). The Atlantic Forest of South America: biodiversity status, threats, and outlook. Washington: Island Press, 2003. p. 43-59.

SÆTHER, O. A. Some Nearctic Podonominae, Diamesinae and Orthocladiinae (Diptera: Chironomidae). Bulletin of the Fisheries Research Board of Canada, Ottawa, v. 107, p. 1-154, 1969.

SÆTHER, O. A. Glossary of Chironomid morphology terminology (Diptera: Chironomidae). Entomologica Scandinavica, Supplement, Lund, v. 14, p. 1-51, 1980.

SÆTHER, O. A. Orthocladiinae (Diptera: Chironomidae) from the British West Indies, with descriptions of Antillocladius n. gen., Lipurometriocnemus n. gen., Compterosmittia n. gen. and Diplosmittia n. gen. Entomologica Scandinavica, Supplement, Lund, v. 16, p. 1-46, 1981.

SÆTHER, O. A. Orthocladiinae (Diptera: Chironomidae) from SE U.S.A., with descriptions of Plhudsonia, Unniella and Platysmittia n. genera and Atelopodella n. subgen. Entomologica Scandinavica, Lund, v. 13, p. 465-510, 1982. 